\title{
ABOUT THE STATE OF THE WORLD WHEAT MARKET AT THE CURRENT STAGE
}

\author{
Pogorelyy M.U., Associate Professor \\ National Research University «Belgorod State University», Belgorod, Russia \\ E-mail: pogorelii@bsu.edu.ru
}

\begin{abstract}
The author considers the Phillips curve in the historical aspect. In the article there is a mention that there were examples when the Phillips curve was not confirmed. Then the author goes on to describe the post-crisis economic situation. The author refers to the food problem as a global problem, which has been designated in the papers of the Club of Rome. Then the author characterizes world wheat production for the period 2003-2013. The author gives an example that shows the volatility of the wheat market (CBOT). The author explains why he uses quotations of forward contracts, and not in the spot market. The author scrutinizes the quotations of СВОT wheat futures contracts in the paper. The author substantiates the need for an econometric model in the research process of futures CBOT wheat prices. The author justifies the chosen scientific approach that defines the methods of research and research model. The author uses econometric approach in the paper. The author uses linear regression as a method of the research. The author creates the equation of linear regression using the software. The author makes a conclusion that there is a certain linear relationship between the price of the futures contract CBOT wheat and the level of unemployment in the United States during the period. The author verifies the effect of Phillips curve. Results of this paper allow the analyst to make informed pricing decisions on the organized market of wheat trade in the medium term.
\end{abstract}

\section{KEY WORDS}

Food problem; World wheat production; Futures contracts; CBOT wheat; Price fluctuation; Factors; Econometric model; Unemployment rate; Inflation; Phillips curve; Correlation coefficient; Linear regression.

We observed adverse climatic conditions in recent times. Severe drought in the United States took place in the summer of 2013. The drought was observed in the states of Oklahoma, Texas, Nebraska.

There was a threat of food shortages in Yakutia due to shallow waters in November 2013. Abnormal hot weather, prolonged lack of precipitation were observed in the central regions of Russia in the summer of 2010, 2012. A catastrophic flood occurred in July 2013 in the Far East of Russia and northeast China because of heavy rains and increased water level in the river Amur. In addition, severe drought prevails in 11 provinces in China in the summer of 2013. Drought is observed for four consecutive years in China.

In Ukraine, the rainfall deficit, reducing the moisture in the soil in the fields of Ukraine had a negative impact on the yield of crops.

The drought took place in Pakistan from July to September 2013.

The fields become parched wasteland, water scarcity spoil millions of hectares of farmland. As a consequence, prices for cereals are rising presumably. Such a situation requires an analysis of the state of the wheat market in the long term.

\section{THEORETICAL BACKGROUND}

In 28-th of November, 1961 Professor A.W. Phillips represented his idea of correlation between inflation and unemployment, illustrated by Phillips curve at the London School of Economics and political Science [1]. However, the economic situation in the different countries in the 1970s refuted the idea of Professor Phillips A. W. The authors discussed the Phillips curve in their articles: Butler D., [2] Cottrell A. [3], Friedman M.[4], Hargreaves-Heap S.P. [5], Lipsey R.G. [6], Lucas R.E. [7], Malkina M. [8],Myatt A [9], Palley T.I. [10], Phelps E.S. [11], Rozmainsky I.V. [12], Islam F., Hassan K., Mustafa M., Rahman M. [13]. The 
supporters of the theory of Keynes recognized that a clear inverse relationship between inflation and unemployment did not exist.

In our days the economies of different countries are going through a period of recovery from the global economic crisis of 2008. "Nevertheless, the global financial crisis in 2008 is likely to cause similar declines of aggregate output in all regions" [14, p. 11]. Analysts are turning to the ideas of prominent scientists in search of a way out of the situation. "The economic downturn in developed countries may thus, have significant impact on developing countries through trade, net foreign direct investment (FDI) inflow and remittances as well as financial contagion and spillovers for stock can affect the volume of investable income in developing countries. Countries around the world have approached this whirlwind pragmatically, prompting emergency funding support for relevant sectors, thereby mitigating the impact of the crisis on economies as well as avoiding the entire collapse of the international financial system." [15, p 3]. We observed for the last period certain crises in the economies of different countries - lower incomes, increased unemployment, reduced consumption, reduced liquidity in the micro level. We know that high unemployment negatively affects real incomes, purchasing power and the level of consumption in general. "The current financial crisis has effected every economy in the world, including the developing economies. The crisis, which began in the United States, has weakened the financial markets both in Europe and in the emerging economies. This case has resulted from globalization phenomenon. Because globalization has demonstrated that the world economy became integrated and there cannot be a major downturn in the world's richest economy without implications for every other economies" [16, p.32].

Uninterrupted supply of the world's population with food is an important issue in the present period. The food problem in all ages created a serious threat to human health, the functioning of society as a whole. The Club of Rome, since the founding, defined as the global food problem. The Club of Rome examines food problem at the moment. "As both food and nonrenewable resources become harder to obtain in this simulated world, capital is diverted to producing more of them. That leaves less output to be invested in basic capital growth" [17].

The importance of the food problem is obvious. "In the 21st century, the growing population is putting growing pressure on agriculture to produce enough food. In addition, changing consumption patterns and increasing land use for energy production purposes are putting further demands on agriculture. Per capita food production has increased by more than 40 percent in the last 50 years, mainly due to the extensive expansion of irrigated land and to improved use of fertilizers. These trends are visible in all of the world's regions" [18]. A key element in solving the food problem is wheat production (Diagram 1).

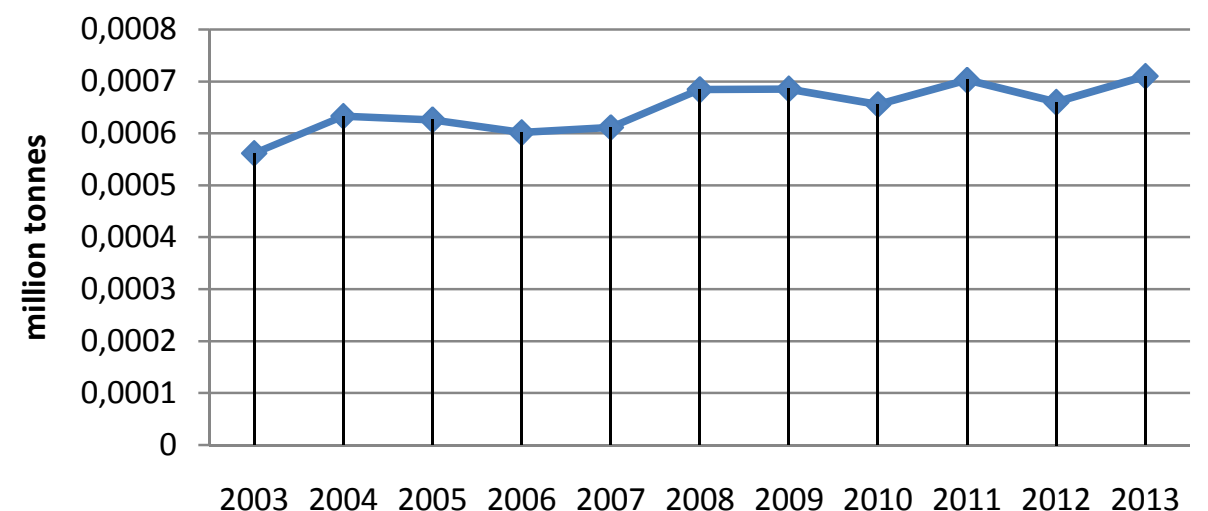

period

Diagram1 - World wheat production 2003-05 September 2013 [19] 
World wheat production increased over the past 10 years (148,3 million tones). In our opinion, it is advisable to consider such factors as price. We carried out monitoring of the price of futures contracts on the CBOT - wheat for the period 07.10.2012 - 07.30.2012, the following data were obtained (Diagram 2).

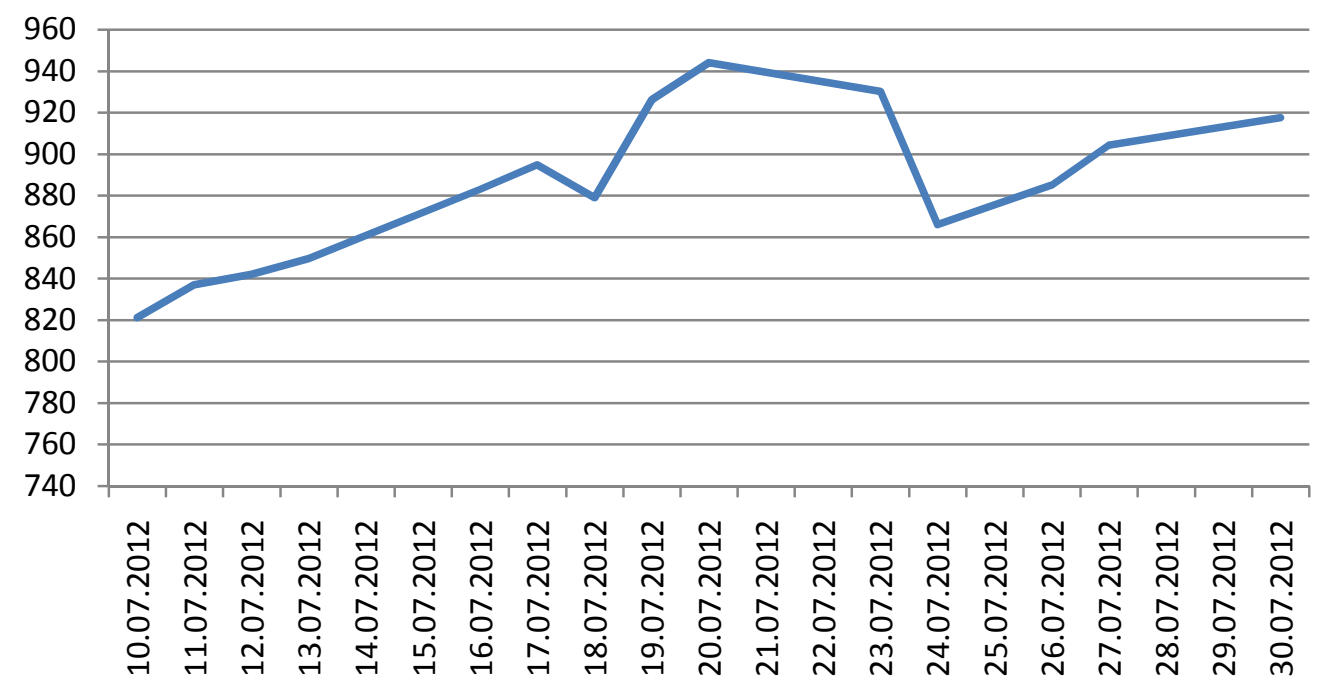

Diagram 2 - The world price of wheat, CBOT [20]

It is obvious that the current state of the world wheat market characterized by a degree of volatility.

It should be explained, that we appeal to the market of futures contracts, because futures contracts are traditionally seen as tools of the market that allow: banks - lenders to hedge the risk of adverse changes in the interest rate on the loan provided (this is important in the post-crisis economic period); to insure the risks of decline in market value of financial assets; exporters and importers partially neutralize the risk or avoid the risk of an unfavorable price fluctuations; buyers and sellers of wheat to minimize price risk.

Quotes futures contracts on wheat serve as a useful indicator in a certain degree of volatility of the global wheat market. Identifying trends quotations of futures contracts in the short and medium term, allows the analyst to make the right decision.

\section{RESEARCH MODEL}

This situation determines the need for scientific research methods of its state to find a certain degree of predictability.

We should identify the methods of the research. We can apply mathematical and statistical methods. Referring to the opinion of Mullineux A.W. "Despite the voluminous empirical work of the NBER and the work of economists, a number of questions remain unsolved...It is of crucial importance because the analysis of business cycle requires that it must somehow first be separated from trend and seasonal influences on the time series. The appropriate method of decomposition will not be the subtraction of a (log) linear trend from the deseasonalised series if the trend is not $(\log )$ linear. Secondly, to what extend is the cycle endogenously and exogenously? Most business cycle assumes that linear models can be used to describe an economic system which is subjected to shocks. The stochastic linear models employed can replicate observed macroeconomic time series reasonably well because the time series they produce possess the right degree of irregularity in period and amplitude to conform with actual realizations... Because the estimated linear econometric models display heavy dampening, cycle analysis have increasingly turned their attention to trying to identify the sources of the shocks that offset this dampening and produce a cycle" [21]. We agree with the opinion and we should use the econometric model. 


\section{RESEARCH METHOD}

Professor of Economics and Finance, University of Chicago Business School Victor Zarnowitz, exploring in his work «Signals and Confirmations of Economic Change» economic cycles in the U.S. economy for the period from January 1948 to December 1975, said: "Data for cyclical indicators provide useful information for current business analysis and forecasting-this positive but general assessment is surely supported by the surveyed record. But it is important to recognize more specifically both what can and what cannot be reasonably expected of this approach.... But the same is true as well of similar applications of other systems of data and techniques in wide use, e.g., econometric models and anticipations surveys. And all this is entirely consistent with the actual treatment of these various techniques by economists with professional interest and expertise in the area, an approach which implies that indicators, models, and surveys are all potentially productive inputs into the process of improving our knowledge of how the economy "works" and our predictions of how the economy is likely to fare" [ 22, p.15-16].

At the first stage, we collected the available statistical data about the quotation of one bushel of wheat on the Chicago Mercantile Exchange since 29 June 2012 to 24 April 2013 using information sites http://europe.wsj.com; http://data.bls.gov/timeseries/LNS14000000.

At the second stage, we make a statistical table that contains the necessary numerical values for compiling an econometric model (Table 1).

Table 1 - The statistical distribution of the sample for the research

\begin{tabular}{|c|c|c|c|c|c|c|c|c|c|c|c|}
\hline 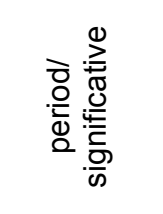 & $\begin{array}{l}\stackrel{N}{\Phi} \\
\stackrel{\Xi}{5}\end{array}$ & $\begin{array}{l}\stackrel{N}{7} \\
\frac{2}{3}\end{array}$ & $\begin{array}{l}\stackrel{N}{5} \\
\stackrel{5}{5} \\
\frac{5}{2}\end{array}$ & 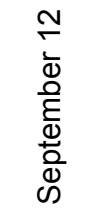 & $\begin{array}{l}N \\
\frac{1}{\Phi} \\
\frac{0}{0} \\
\frac{0}{0} \\
0\end{array}$ & 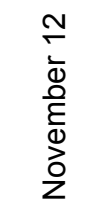 & 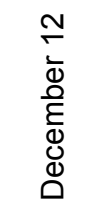 & 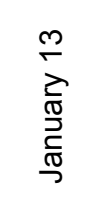 & 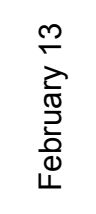 & $\begin{array}{l}\frac{m}{\Gamma} \\
\frac{0}{0} \\
\frac{\pi}{2}\end{array}$ & 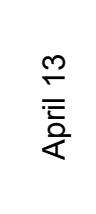 \\
\hline $\begin{array}{l}\text { variations } \\
\left(x_{i}\right)^{1}\end{array}$ & 821,2 & 944,0 & 917,5 & 870,0 & 870,2 & 869,2 & 863,0 & 754,5 & 755,6 & 706,5 & 716,5 \\
\hline $\begin{array}{l}\text { frequency } \\
\qquad\left(n_{i}\right)^{2}\end{array}$ & 0,082 & 0,082 & 0,081 & 0,078 & 0,079 & 0,078 & 0,078 & 0,079 & 0,077 & 0,076 & 0,075 \\
\hline
\end{tabular}

The statistical distribution of the selection was presented in the form of a number of statistical distributions in Table 1. We put data of the price of futures contracts on CBOT wheat $\left(x_{i}\right)$ in the first column of the Table 1. We place the corresponding values of the unemployment rate in the U.S.A. $\left(n_{i}\right)$ in the second line.

We should apply such method of econometric research that allows us to identify the presence or absence of a relationship between variables, and measures the degree of this connection. Thus, we use the correlation coefficient as the econometric method of research.

\section{HYPOTHESIS TESTING}

We received statistical data in the course of observation. Accordingly, we distinguish list of variants $\left(x_{i}\right)$ and the corresponding frequencies $\left(n_{i}\right)$, where $\left(x_{i}\right)$-prices of futures contracts CBOT wheat, and $\left(n_{i}\right)$-unemployment rates in the United States.

We assume that there is certain dependence between the price of CBOT wheat and the level of unemployment in the United States (Figure 1).

It is necessary to calculate the correlation coefficient. It is well known that the correlation coefficient has its peculiarities: correlation coefficient is in the range from -1 to 1 ; if the correlation coefficient is equal to \pm 1 , the researched variables strongly linearly related.

\footnotetext{
1 http://uk.wsj.com/mdc/public/page/mdc commodities.html

2 http://data.bls.gov/timeseries/LNS14000000
} 


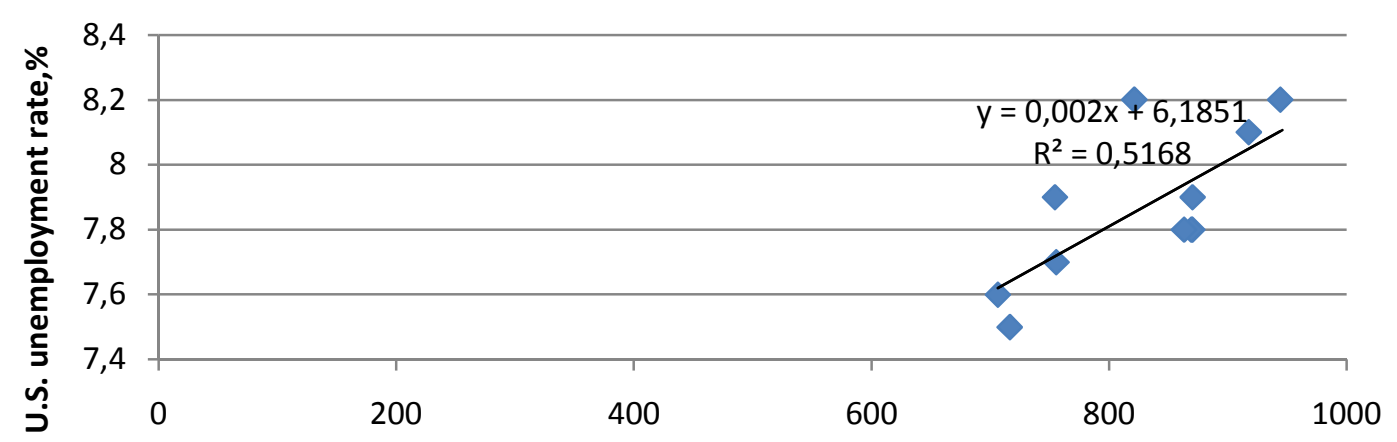

CBOT wheat price (cents per bushel)

Figure 1 - The linear dependence of futures prices CBOT wheat (cents per bushel) and the unemployment rate in the U.S. (\%) for the period from 06.29 .2012 by 04.17 .2013

Our calculations show that the value of the correlation coefficient is 0.72 The value of the correlation coefficient 0.72 indicates the presence of a certain linear relationship between the researched variables - the price of a futures contract CBOT - wheat (cents per bushel) and the level of unemployment in the United States (\%) for the period from 06.29.2012 by 04.17.2013.

We have received direct proportion between the criteria. It contradicts the Phillips curve, according to which a decrease in the unemployment rate should increase in wheat prices because of rising inflation. We should pay attention to this contradiction.

On the one hand, there are academic papers that criticize the Phillips curve.

"As I have argued elsewhere (1972), theories developed along these lines will not place testable restrictions on the coefficients of estimated Phillips curves or other single equation expressions of the tradeoff. They will not, for example, imply that money wage changes are linked to price level changes with a unit coefficient, or that "long-run" (in the usual distributed lag sense) Phillips curves must be vertical. They will (as we shall see below) link supply parameters to parameters governing the stochastic nature of demand shifts" [23, p.327].

On the other hand, the Phillips curve is correct. We consider the equation 2.

$$
\frac{d \pi}{d t}=\gamma\left(g-g_{n}\right)+\epsilon_{2} "(2) "
$$

Equation (2) describes the behaviour of inflation. It is either called the price equation (Fair 2000: 2) or the aggregate supply equation (Allsopp and Vines 2000:10). As before $\epsilon_{2}$ stands for a temporary shock to inflationary forces (due to expectations or a cost shock), while $g_{n}$ is the natural growth rate of output, or the growth rate of potential output, which is equal to the sum of the labour force growth rate and the rate of technical progress. The rate of price inflation is give by $\pi$, and hence equation (2) says that the change in the inflation rate is positive whenever the growth rate of output demand exceeds the natural growth rate or when there is some kind of inflationary shock. This equation, as is clearly pointed out by Allsopp and Vines (2000:10) and Taylor (2000a: 92) is a variant of the vertical Phillips curve - the standard expectations-augmented Phillips curve; it can be considered as the equivalent of the NAIRU, as shown by Arestis and Sawyer (2000: 536). It is the accelerationist equation, since the inflation rate will accelerate whenever the growth rate of demand exceeds the natural rate of growth" [24].

Opinion of Friedman allows us to understand some of the contradictions of the Phillips curve better. "You will recognize the close similarity between this statement and the celebrated Phillips Curve. The similarity is not coincidental. Phillips' analysis of the relation between unemployment and wage change is deservedly celebrated as an important and original contribution. But, unfortunately, it contains a basic defect-the failure to distinguish between nominal wages and real wages-just as Wicksell's analysis failed to distinguish 
between nominal interest rates and real interest rates. Implicitly, Phillips wrote his article for a world in which everyone anticipated that nominal prices would be stable and in which that anticipation remained unshaken and immutable whatever happened to actual prices and wages." [25, p.8] We share the opinion the authoritative scholar. "Stated in terms of the rate of change of nominal wages, the Phillips Curve can be expected to be reasonably stable and well defined for any period for which the overage rate of change of prices, and hence the anticipated rate, has been relatively stable. For such periods, nominal wages and "real" wages move together. Curves computed for different periods or different countries for each of which this condition has been satisfied will differ in level, the level of the curve depending on what the average rate of price change was. The higher the average rate of price change, the higher will tend to be the level of the curve. For periods or countries for which the rate of change of prices varies considerably, the Phillips Curve will not be well defined. My impression is that these statements accord reasonably well with the experience of the economists who have explored empirical Phillips Curves" [25, p.9]. We share the point of view of a scientist Friedman M.

\section{CONCLUSIONS}

We think, that the effect of the Phillips curve is not observed in relation to the quotations of СВОТ wheat in the current economic conditions, because there are the following factors: the high level of economic globalization; the high level of government regulation of the economy; there is a high and sustainable level of supply of crops such as rice and maize, which reduces the demand for wheat; the law of supply and demand, reflected in raising level of global wheat production, which increases the supply of wheat and lowers the price for it.

\section{REFERENCES}

1. Phillips, A. William Housego. (1962). Employment, inflation and growth: an inaugural lecture, 28 November 1961, the London School of Economics and political Science. London: G. Bell.

2. Butler D. Micro-economic foundations of employment and inflation theory/Butler D. // The Journal of Industrial Relations. 1972. Vol. 14. pp. 76-81.

3. A.Cottrell. (1992). Post Keynesian Monetary Economics: A Critical Survey/ A.Cottrell// Cambridge Journal of Economics. 1994. Vol. 18. pp. 587-605.

4. Friedman M. The Role of Monetary Policy / Friedman M.// American Economic Review. 1968. Vol. 58. pp. 1-17.

5. Hargreaves-Heap S.P. Choosing the Wrong Natural Rate: Accelerating Inflation or Decelerating Employment and Growth / Hargreaves-Heap S.P. // Economic Journal. 1980. Vol. 90. pp. 611-620.

6. Lipsey R.G. The Relationship Between Unemployment and the Rate of Change of Money Wage Rates in the U. K. 1862-1957: A Further Analysis / Lipsey R.G // Economica. 1960. Vol. 27. pp. 1-31.

7. Lucas R.E. Some International Evidence on Output-Inflation Tradeoffs/ Lucas R.E. // American Economic Review. 1973. Vol. 63. pp. 326-334.

8. Malkina M., Rozmainsky I.V. To the formation of institutional theory of inflation// Journal of Institutional Studies. 2013. Vol. 5. pp. 69-87.

9. Myatt A. On the Non-Existence of A Natural Rate of Unemployment and Kaleckian Micro Underprinnings to the Phillips Curve / Myatt A. // Journal of Post Keynesian Economics. 1986. Spring. pp. 447-462.

10. Palley T.I. Post Keynesian Economics: Debt, Distribution and the Macroeconomy. L.: Macmillan, 1996.

11. Phelps E.S. Money Wage Dynamics and Labour Market Equilibrium / Phelps E.S. // Journal of Political Economy. 1968. Vol. 76. pp. 678-711. 
12. Rozmainsky I.V. Contemporary analysis of Philips' theoretical curves: methodological aspects from postkeynesian view/ Rozmainsky I.V.//Terra Economicus. 2006. Vol. 4. pp. 48-60.

13. Islam F., Hassan K., Mustafa M., Rahman M. The empirics of US Phillips curve: a revisit/ Islam F., Hassan K., Mustafa M., Rahman M. // American Business Review. 2003. Vol. 21. pp. 107.

14. Fidrmuc Ja., Korhonen I. The impact of the global financial crisis on business cycles in Asian emerging economies/ Ja. Fidrmuc, I. Korhonen. // BOFIT Discussion Papers. 2009. № 11. pp. 01-29.

15. Mkpado M. Global financial crisis and agrarian households' income, remittance and prices in rural Nigeria amid policy responses/ M. Mkpado // Russian Journal of Agricultural and Socio-Economic Sciences. 2012. Vol. 6. pp. 3-9.

16. Bahce A., Karaaslan $\mathrm{Yu}$. Effects of global crisis on structural policies and financial regulations: the comparison of OECD economies/ A. Bahce, Yu. Karaaslan // Perspectives of Innovations, Economics and Business. 2009.Vol. 3. pp. 32-34.

17. http://www.jayhanson.us/page25.htm

18. http://www.fao.org/docrep/017/i3138e/i3138e02.pdf

19. http://www.fao.org/worldfoodsituation/csdb/en/

20. http://europe.wsj.com/mdc/public/page/mdc_commodities.html

21. Mullineux A.W. Business cycles and financial crises [электронный ресурс]/ Режим доступа: http://bookboon.com/en/business-cycles-and-financial-crises-ebook

22. V. Zarnowitz, "Signals and Confirmations of Economic Change," Selected Paper No. 46, Graduate School of Business, University of Chicago. pp. 20. https://www.chicagobooth.edu/ /media/2967F05E0E5246278875955C2F8F5E78.pdf

23. Lucas R.E. Some International Evidence on Output-Inflation Tradeoffs/ Lucas R.E. // American Economic Review. 1973. Vol. 63. pp. 326-334.

24. http://www.bancentral.gov.do/trabajos_investigacion/paperNo08.pdf

25. Friedman M. The Role of Monetary Policy / Friedman M.// American Economic Review. 1968. Vol. 58. pp. 1-17. 